\title{
The Ecopoetics of Reparation
}

\section{Sebald, Darrieussecq, and Barthes Enda McCaffrey}

This article explores the displacement of trauma to the ecopoetics of reparation. Drawing on theories of reparation ${ }^{1}$ and textual ecopoetics,,$^{12}$ I examine the ways in which a textual turn to nature-—une sensibilité écologique"로 that encompasses the atomic, cosmological, mineral,

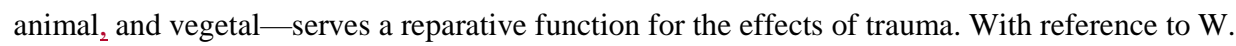
G. Sebald's The Emigrants (2002), Marie Darrieussecq's Tom est mort (2007), and Roland Barthes's Journal de deuil (2009), I analyze reparation from trauma from different ecopoetic perspectives: Sebald's gardens, Darrieussecq's cosmos, and Barthes's animalia. The turn to the ecopoetic enables these writers to rethink trauma outside the co-ordinates of chronological time, the mortal (gendered) body, anthropocentrism, self and identity, and inside an ecopoetical discourse where identity and language is reformed and relearned, and critically where trauma is reframed in a reparative discourse of an "eco-parloir"4 underpinned by language, imagery, and cultural reference. $\frac{3}{}$

\section{Trauma Theory}

Critics acknowledge that trauma cannot be represented as past but is perpetually re-experienced in a present..$^{45}$ Intrinsic to this re-experience is the construction of trauma retroactively and the creation of distance from an event in order to realize its impact. I want to pursue another line of enquiry that addresses trauma in the context of reparation. Marianne Hirsch's recent work on epimemory ${ }^{6}$ is a valuable exploration in this area..$^{\frac{5}{}}$ Positing epi-memory as a counterpoint to 
historical and gendered accounts of trauma, Hirsch identifies the human epidermis as a space of projection to channel memory. Central to her argument is how a methodology of the skin can be transformative in dislodging the personalization of trauma and producing political and aesthetic strategies to repair the experience of trauma. This article sits within this broad reparative framework by investigating the role of ecopoetics on the experience of trauma. Drawing on Freud's concepts of "acting out" and "working through" trauma, Dominick LaCapra (2001) and Mireille Rosello (2010) equate the concept of "acting-out" situations of trauma with a tendency to relive the past. For Freud and LaCapra, this compulsive tendency to repeat trauma is destructive and self-destructive. ${ }^{67}$ Related to this tendency of "acting out" but also a countervailing force; is the concept of "working through," where the tendency is to gain critical distance from a traumatic event. Distinguishing between these two concepts is problematic for LaCapra. He claims that the lines between identification with the other ("acting out") and transcendence of the other ("working through") are blurred..$^{78}$ However, he acknowledges that neither concept points in the direction of a "redemptive" narrative where redemption is an overarching narrative that resolves the traumatized's experience. Mireille Rosello replaces redemption with reparation as an accommodation between "acting out" and "working through."She echoes LaCapra's argument that two narratives are not only at play but also interact. Interaction is therefore an opportunity for a new type of "breaking free." ${ }^{89}$ For Rosello the reparative is a dynamic process in which there is an attempt to work through the past without denying one's implication in it and without denying the after-effects of trauma. Set against this interactive and non-redemptive context, I read the reparative as a means of "imagining an alternative out of a seemingly doomed past." $=-210$ This approach to the reparative, as Rosello suggests, can be located within a new type of breaking free; not a breaking free from the trauma 
of the past (itself impossible as claimed by LaCapra and Rosello) but, as I claim, into the positive displacement of trauma to the reparative impact of nature. Ecopoetics (distinct from the AngloSaxon variants of ecocriticisim ${ }^{14}$ ) is primarily a French innovation ${ }^{12}$ that addresses how texts approach and write nature: $:^{10} \div$ "It emphasizes, through the etymology of the poiein, what is literary." ("il met davantage l'accent, à travers l'étymologie du poiein, sur le fait littéraire." $2^{1 \frac{1}{3}}$ ["It emphasizes, through the etymology of the poiein, what is literary."]-More aesthetic than political, ecopoetics looks to how literary texts represent the historical continuum between the human and non-human world. In this respect, ecopoetics is a form of relationality ${ }^{14}$ between species, $\frac{12}{}$ where the borders between them are subject to critical inquiry. Nature and natural elements are not simply images at the service of the writer/text. From an ecopoetical perspective, nature is viewed as autonomous with its own value, ethics, and agency. Ecopoetics therefore has the capacity to pose an ontological challenge in the way natural elements (mineral, vegetal ${ }_{2}$ and cosmological) are constituted in relation to humankind, and how they are inscribed in an historical continuity that links the past with the present. Relationality heightens the co-presence and inter-dependence between human and non-human ${ }_{2}^{13 \underline{5}}$ and in this way ecopoetics affords nature the potential to contribute to the formation of a living and organic memory. This article explores the relation between trauma and this turn to ecopoetics. Locating trauma within ecological contexts (including birdlife, horticulture, and their distinctive socio-biological, eco-, and perceptive systems) will enable us to explore the situational and reparative context for the traumatized..$^{146}$

\section{Sebald's hortus conclusus}

Patrick Chamoiseau considers the ethical and ideological dimensions of ecopoetics when he reminds us of the principles at stake in ecopoetic discourse $;$; the centrality of change and 
renewal, and the principle of relationality that links human and non-human in an ecosystem in which all living beings partake. ${ }^{157}$ At the heart of Chamoiseau's relationality is a nonanthropocentrism (a "deep ecology"18 or "interspecies literature"1 ${ }^{169}$ ) in which the representation of the natural world is not hierarchically oriented and where the non-human assumes "narrative rights" ("droit de cité narratifnarrative.." $)^{1720}$ ["narrative rights"]. Non-anthropocentric relationality undermines the autonomy of the ego-self and promotes a conception of identity ("eco-self") as a bridge to the non-human whilest acknowledging the situational context of the human relationship to the ecosphere. Chamoiseau elaborates on the significance of the garden in this context. The garden is viewed primarily as a space of relation where humans participate in the world's ecosphere. Gardening, for example, enables human beings to find tranquillity: "It's the contact with the vegetal that gives peace." ("C'est le contact avec le végétal qui donne la paix." $2^{1821}[$ "It's the contact with the vegetal that gives peace"]. Contact with the earth connects mind and body, oneself with others, through its capacity to access "an ancient sensibility based on the vegetal, the earth, vital forces." ("une vieille sensibilité basée sur le végétal, la terre, les forces vitales." ${ }^{1922}$ ["an ancient sensibility based on the vegetal, the earth, vital forces"]. Through this sensibility nature is not just restored to its centrality at the heart of human experience, ${ }_{2}$ but it reinforces the historical continuity that links human and non-human, past and present.

We can see this relational continuity in W. G. Sebald's representation of nature, animals, and particularly the garden. ${ }^{203}$ Sebald's The Emigrants brings together the "working through" and "acting out" concepts in an uneasy alliance. There are no survivors in this work. Characters do not confront the past. The Holocaust has silenced them. Characters are stuck in "acting out" trauma as identification, and suicide is the expression of this identification. However, I would 
like to outline another perspective drawing on the reparative as a new type of breaking free, in which the silence of trauma is displaced to the communicative energy of nature and the cosmos. Gardens feature prominently in the four stories of this collection. A modern-day secular variation on the medieval hortus conclusus - an enclosed space associated with depictions of the Virgin Mary-Sebald's gardens are spaces of repose, consolation, and rebirth. In Dr. Henry Selwyn, the narrator has traced Henry in his later years to East Anglia. As they become acquainted, Henry tells of his deportation during the war. The experience broke him: "Since then, almost my only companions have been plants and animals." ${ }^{214}$ On one level, nature is a way for Sebald to convey the residual impact of the Holocaust. On another, residue implies restorative potential as indicated in the "bunch of white roses with twines of honeysuckle"25 delivered to the narrator before Henry's suicide. ${ }_{-}^{22}$ - Years after Henry's suicide, the narrator reads a newspaper article stating that "the remains of the Alpine guide Johannes Naegeli [Selwyn's best friend] . . had been released by the Oberaar glacier, seventy-two years later." ${ }^{236}$ The hiker's body had been preserved by lime trees (linceuls in the French newspaper headline). These references to natural phenomena are not without significance. The white rose symbolizes innocence and purity, and as the traditional bridal rose it also points to new beginnings. Die Weiße Rose was also a nonviolent resistance group in Nazi Germany consisting of students from the University of Munich. Implicitly, resistance (political, ontological, biological) is seen to endure beyond suicide in the political and ecological rejuvenation of the white rose as gift and the sustaining nourishment provided by the edible sweet nectar of the honeysuckle. Nature ${ }_{2}$ in other words ${ }_{2}$ acts in its own time and place, releasing a dead body after seventy-two years, a feat only possible by lime preservation. Natural preservation emerges as the template against which life and death are reimagined. In this turn to nature and in the absence of a language to express trauma (an aphasia 
triggered by "acting out" trauma) Sebald sees in the organic autonomy of nature and how it relates human and non-human ecologies a means by which to channel a process of "working through" trauma. Paul Bereyter undergoes a similar reparative transformation via ecological interventions. A passionate teacher loved by his pupils, he loses his job during the war because he is half-Jewish. He displaces his violence at this betrayal to his students, which is soon allayed by his passion for gardening ("which . . . he loved more than anything else-" ${ }^{247}$ ). In his final years, Paul restores the neglected garden in his adopted home of "Bonlieu" (appropriately named "good place" in French as opposed to its pejorative homonym "Banlieue"). Paul and Henry lived fulfilled lives prior to the Holocaust. Afterwards, they retreat into themselves and into the ecological space of gardens, characterized by their beauty, diversity of plant life, and rehabilitative potential. The garden does not erase the irreparable trauma of the past. ${ }^{258}$ However, reclaiming the neglected gardens facilitates a means of working through the past; reclaiming "helps us reread the metaphor of a diseased past as a problematic construction" 29 or, I would argue, reconstruction. ${ }_{-}^{26}$ - Henry's and Paul's passion for gardens may have been silenced during the war, but it has not disappeared. This passion, and by implication their respective memories and selves, returns as a matter of involuntary organic necessity. Henry finds fulfillment in a garden that has been "left to its own devices." ${ }^{2730}$ Even from the most abandoned of natural ecologies, there emerges from its own devices - by dint of its own self-generating agency as Rosello reminds us in the context of involuntary memory and Kullberg in the context of ecopoetic sustainability $\underline{28}^{231}$ - the reparative force of nature that counterbalances the eventual violence that Henry (and others) inflict mpon themselves. It is the garden (not Henry, Sebald 2 or the narrator) that is the agency of this counter--energy.

Ambros Adelwarth extends the reparative theme from nature to cosmos, connecting in the 
process trauma, gender, and reparation. Ambros and Cosmo are two gay Jews. Upon their return to America after the war, Cosmo suffers two breakdowns due to events in war-torn Europe. After retreating to a secluded garden, he ends up in a sanatorium where he dies "without saying a word or moving a muscle."롤 Ambros survives longer than Cosmo until he succumbs to depression, unable "to shape a single sentence, nor utter a single word, or any sound at all." ${ }^{30} \underline{3}$ On the final day of his shock treatment, Ambros forgets his appointment time and finds himself gazing out over the gardens of Ithaca in upstate New York. He apologizes to the doctor, saying ${ }_{2}:$ "It [the appointment] must have slipped my mind whilst I was waiting for the butterfly man." ${ }^{314}$ After telling of his death, Dr. Abramsky waves the narrator good-bye describing a gentle arc with the goose wing in the darkening air. Amidst death, the butterfly and the goose wing signal reparative transformation. The butterfly is a living organism capable of changing entirely its genetic structure during the process of transformation, which makes it a unique example of total transformation, self-transformation ${ }_{2}$ and reincarnation. The arc created by a goose wing gestures to natural forms of valedictory communication and flight. The goose too, like the quail, has three genera (Anser, Chen, Branta), dating back twelve million years, and many varieties from different parts of the world, including the Egyptian goose, New Zealand goose, and many more. The goose wing invokes non-territorial, trans-historical ${ }_{2}$ and trans-species communication that challenges the barbarity of human (non)-communication in war. These images intersect with the emergence of other cosmic and cosmopolitan identifications that Cosmo and Ambros shared in their former travels across the Middle East: ${ }^{35}$

Above us the Milky Way ... If I look straight up I can see the Swan and Cassiopeia. They are the same stars I saw above the Alps as a child and later above the Japanese house in its lake, above the Pacific, and out over Long Island Sound. I can scarcely believe I am the same person, and in Greece. But now and then the fragrance of juniper wafts across to us, so it is surely so. ${ }^{32} 6$

Star-gazing offers a cosmic ontological vision, collapsing time and space, gender and 
individuality, and interacting with nature in the metonymic image of juniper (rather than the geographic location of Greece) as the alternative register of longitudinal and latitudinal belonging. It's a cosmo(politan) vision that Sebald locates in the topology of the city of Constantinople and its garden cemeteries (as opposed to the barren landscape of Jerusalem described as la terre maudite where "there is no sign of life, not an animal scurrying by or even the smallest bird in flight." ${ }^{337}$ In Constantinople the passing of the dead is venerated by nature:

For, like Death itself, the cemeteries of Constantinople are in the midst of life. For everyone who departs this life, they say, a cypress is planted. In their dense branches the turtle doves nest. When night falls they stop cooing and partake of the silence of the dead. Once the silence descends, the bats come out and flit along their ways. ${ }^{348}$

Nature emerges as the reparative alternative through which Sebald's characters preserve this vision. Reparation is evident in the birdlife, including moths and pigeons ${ }_{2}{ }^{359}$, and particularly the quail at the end of this story resting on Cosmo's breast as he sleeps through the night and which that then takes flight as he stirs at daybreak. The quail is the collective name for several genera of mid-sized birds, divided into Old World Quail (from the Phasianidae family) and New World Quail (Odontophoridae). Old World Quail include the genus common quail, stubble quail, rain, brown, blue ${ }_{2}$ and harlequin quails. The New World Quail is more exotic in genus. The unknown genus of quail perched on Cosmo invites us to consider the quail's local and universal meanings and their respective reparative possibilities within Sebald's wider cosmopolitan imagination.

Sebald uses this ecopoetic discourse to project an alternative vision of life post-Holocaust. His characters find temporary reparation from trauma in the horticultural and vegetal practices of gardens before their final suicides. The garden's organicity connotes the nostalgia for a lost innocence - a pre-Holocaust cosmopolitanism and inter-generational identification with the past mediated through nature. In these garden practices Sebald's characters forge reparative links with their ancestral heritage $\frac{3640}{}$ and an Arcadian homosociality. 


\section{Darrieussecq's Cosmos and Planisphere}

Marie Darrieussecq's novel Tom est mort tells the story of a mother grieving the death of her nine-year--old son, ${ }^{41}$ and where-the scale of the grieving process stretches over a ten--year period and over a geography that includes Paris, Vancouver, and Sydney. $\frac{37}{}$ The novel is also a critique of the way grieving has been institutionalized as a religious and commercial practice. Grieving has its habits $;$; the morgue, the funeral parlor, choosing flowers, cremation versus burial, urns or worms. Grieving as an institution has its particular space-what Darrieussecq calls the white room ("la chambre blanche") of public grief. However, it is the red room ("la chambre rouge") which-that is of interest. Here Tom's death is codified not as a finality determined by the institutions of death but as a natural and cosmic continuity that inscribes itself within the living. Framed by the cosmos, as opposed to Judeo-Christian or material signifiers, Tom's death belongs outside his death to the universality of death, and $\underline{\text { it }}$ is expressed in a number of ecopoetic ways, from grains of sand to burial practices of the Pharaohs.

Emma Wilson has observed that "the loss of a child knows no repair or reparation"; it is a "limit subject, a subject which reaches or exceeds the bounds of representation and normal, narrative resolution." ${ }^{3842}$ Whilest Wilson refers primarily to cinema, her statement defines a "limit subject" beyond which there can be no narrative resolution. This absence of narrative resolution is problematic even though critics would appear to concur on its value. Colette Trout equates the narrator's grief-stricken state to a "psychological fantastic" without resolution or explanation of its consequences or benefits. ${ }^{3943}$ Simon Kemp concludes that the narrator's grief is a function of "cognitive dissonance" from which there is no return. ${ }^{404}$ My reservations are linguistic and formal. From the outset of Darrieussecq's novel, grief is experienced as much as a loss of a son as a loss of self ("subject"), and reparation for this loss is intrinsic to the narrator's 
experience of and rehabilitation from grief. In the first instance, loss of self is a loss of ego which that underlines the impossibility of rationalizing grief. Loss of ego also gives way to the emergence of an "eco subject" that enables Darrieussecq to explore a different and limitless subjectivity beyond the limits of motherhood or gender.

On the formal side, the loss of a child and the pain of grief are often channelled through the mother/son relation. Critics of this novel, for example, have highlighted the failure of the parent (mother) to prevent death from happening. ${ }^{415}$ However, I would argue that Darrieussecq transcends Oedipal affiliations by emphasizing that grief is primarily a neuronal loss that can impact all sentient beings. $\stackrel{426}{ }$ Not only has time stopped with Tom's death—opening up an ahistorical zero-time for the exploration of grief - but this exploration invites comparison with an array of human and non-human phenomena. The narrator cannot tell when her son Tom died (f"Time was no longer with me. . . Time had died" [f"Le temps n'était plus avec moi. . Le temps Commented [W4]: Not sure what green double lines means. However, it is OK. It is my translation.

était mort"]). ${ }^{4} \underline{7}$ ["Time narrieussecq situates Tom's death in the recollection of the birth of her other children who were born in spring time and whose births are compared to "otters, or koalas or Tasmanian devils, or lots of other animals." ("des loutres, ou des koalas ou des diables de Tasmanie, ou de beaucoup d'autres animaux." $2^{448}$ ["otters, or koalas or Tasmanian devils, or lots of other animals"]. The comparison with animals is not incidental. Anne Simon claims that Darrieussecq's work positions itself at the juncture between species; humans share an animal sensoriality thich that enables them to widen their perceptions and understanding of themselves. She extends this viewpoint to an interpretation of Deleuze and Guattari's concept of "becoming-animal" ("devenir-animal") ["becoming animal"]. ${ }^{4 \underline{59}}$ Darrieussecq takes grief outside time, space, and gender into nature's forests and beaches and into the far reaches of the cosmos where her son's pulverized atoms 
continue to circulate like a space capsule in the void. By re-framing the deceased Tom in natural and cosmic spaces, Darrieussecq creates a posthuman relationality through his revitalized participation in natural ecosystems. The ecopoetics of this participation are visible in a number of phenomena:-; sea and sand; the earth as a Deleuzian body without organs "traversed by unformed and unstable matters" ("traversé de matières instables non formées" $\underline{4650}^{460}[$ "traversed by unformed and unstable matters"]; and the air/atmo(sphere)_as a topological co-existential space ${ }^{51}$ where relations between interspecies are cultivated and where being/life is resignified beyond the individual mind in abstracted antimatter. $\frac{47}{}$ Darrieussecq extends the ecopoetics of this participation to include a reparative impact. Disillusioned by online networks and talking therapies, the narrator turns to the atmosphere to work through grief. One example of this is the installation of loud speakers in every room of the Sydney apartment to capture the sound of Tom, whose pulsations through the air she believes are testament to his presence and attempts to communicate with the living. The reparative effect of these loud speakers is being able to hear Tom again - albeit as pure sound - and helping the narrator restore her own speech, itself impaired by Tom's death and her subsequent grief. The narrator learns to reconstruct speech, consonants first, then vowels, until she he is able to say: "I articulate." ("J'articule." $)^{4852}$ ["I articulate"]. Reparation is twofold. First, articulation is predicated on the gaseous substance of air and her debt to it in helping her overcome her silence. The language she learns to articulate however ${ }_{2}$ is not one we recognize. It is a new language — a secret esperanto formed from breath: "I forced myself, $t, f, k, p, s$, and Tom replied in the same hollow language, we would find This translation is $\mathrm{OK}$

words that were made of breath... The air propelled itself, spherical, I could hear the sound of the air.:"Ғ. ("Je m'efforçais, $t, f, k, p, s$, et Tom me répondait dans la même langue lacunaire, nous trouvions des mots qui n'étaient que du souufle... L'air se propulsait, sphérique, j'entendais le 


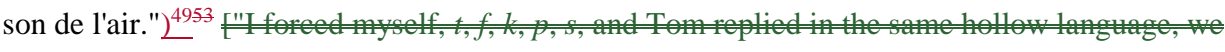
would find words that were made of breath... The air propelled itself, spherieal, I could hear the sound of the air"].Second, this new language (an "eco-parloir") is informed by the sun, sea, sky, and the Australian bush. Non-redemptive and non-spiritual, its "pouvoir consolateur" is communicated via an historical participation in the diverse and harmonious coherence of an ecosystem that puts humans alongside animals, dragons alongside dragonflies, air alongside language. Becoming-world ${ }^{54}$ (or becoming-animal) endears Tom to all living creatures via the earth/cosmos, creating an alternative consciousness that displaces concepts of linearity and memory. $\frac{50}{}$

Darrieussecq also engages in a discourse of mourning that takes us outside the redemptive discourse of substitution and inside a non-anthropocentric and cosmological narrative. Cosmic energy offers another perspective on grief which Darrieussecq's use of the planisphere illustrates. The planisphere is an astronomical instrument of Hellenistic origin in the form of two adjustable disks that rotate on a common pivot. It shows only the stars visible from the observer's latitude. Moving latitudes and hemispheres reveals other stars and depths in the astronomical galaxy. Tom's after-life is magnified within the planisphere of the Pacific where much of his life was spent. The planisphere allows Darrieussecq to break free from chronological time and the traditional cartography of life experiences. Tom's life is not defined by time (on earth, age, date of birth or death) but by his relation to space and locations in space. Being able to link locations in space-time in the compressed space of the planisphere-using images of triangles and capitals (present and absent) — enables the writer to trace a different life-line (or becoming) where chronological time is replaced by cosmological co-ordinates. ${ }^{515}$ In this cosmology, Darrieussecq, I suggest, finds a reparative narrative. Cosmology perpetuates the 
presence of Tom's death in life. He co-exists with his "mother" forever in the atmosphere. The cosmic becomes the source and material of this presence, which the narrator uses to re-create Tom not in a new physical form but as part of an amalgamation of natural properties dispersed in the salt and rock of Uluru (aka Ayers Rock), the minerals and materials of the Blue Mountains near Sydney, the Australian bush, and the syllables and sounds that comprise the potlatch language of the Canadian Indian tribes. The narrator even imagines deconstructing Tom's cremation and sifting through the atoms and ashes with a view to reconstituting him: "Le refaire. Commented [W8]: Insert English translation: "Remake Lui redonner forme." ${ }^{52} 6$

Darrieussecq in short identifies reparation from trauma in an ecopoetical engagement with the ecological landscape of Australia and the cosmos. By linking the experience of trauma to natural elements, Darrieussecq transcends time and gender and finds reparation in the inseparability of present trauma from the pre-histories and aboriginal contexts of which it is a part and through which ecology plays a "scriptotherapeutic,"-57 post-traumatic role. ${ }^{53}$ Ecopoetics affirms Darrieussecq's critique of human hubris. It also enables her to depersonalize and degender the impact of trauma by reconfiguring time, body ${ }_{2}$ and meaning in an aspatial and atemporal void subject only to the forces of gravity, energy, and black holes.

\section{The Ecopoetics of Broken Relationality}

The day after his mother's death (26 October 1977), Roland Barthes began to write notes on sheets of standard paper cut into four. These notes continued until 25 September 1979 and comprise what we know today to be his Journal de deuil published posthumously in 2009. Much of the critical scholarship on this work focuses on the fragmentary style of the journal and the limitations of this form in the narration of grief. ${ }^{548}$ Echoing Darrieussecq's resistance to the institution of grief, Barthes pours scorn on the dubious practice of being able to measure grief in 
terms of recovery. For Barthes, the immeasurable extent of grief is a structure of relationality:

E"grief . . . is the gaping hole left by the loving relation.". ("le deuil . . . est la béance de la relation aimante. $2^{559}[$ "grief ... is the gaping hele left by the loving relation" $]$. Relationality is therefore not fullness of contact, nor is it measured in the "émotivité" experienced by the griever and the grieving. Grief is of another order ("another duration" ["une autre durée"["another duration"]) that is characterized by its continuing brokenness. This relationality is not expressed as "deuil" per se but "chagrin." Barthes views the word "deuil" as an inadequate measure of his grief because of its associations with medicalization, psychotherapy ${ }_{2}$ and time (time traditionally seen as an agent of healing). "Chagrin" ("shagreen"—-meaning rough skin/hide) on the other hand captures grief at an epidermic level where human/animal skin becomes the alternative visible measure of grief's impact. ${ }^{569}$ Claudia Benthien views the skin as a place to characterize subjectivity. More than a literary motif, she argues that the skin is a meaning-bearing surface where grief is projected in the skin and as skin. ${ }^{5761}$ Ladsaria and Singh explore the predilection for animal signifiers of the self in Barthes's work, underscoring the "co-relation between the self and the environment." $=\frac{5862}{=}$ We have evidence in the Journal of this relation between skin and animal in Barthes's choice of the zebra and the erratic lines of the "zébrure" (the stripes on a zebra). A zebra is black with white stripes. Its stripes serve multiple functions from camouflage and visual identification to cooling effects. The stripes are also unique in shape to each animal, varied in presentation and discontinuous:-; vertical on the head and neck and horizontal at the rear and on the legs. Erratic and punctuated ("Zebra markings, the gap in the loving relation"

["Zébrure, béance de la relation d'amour" ${ }^{5963}$ ["Zebra markings, the gap in the loving relation"]), the stripes are a visual reminder of the plurality of Barthes's disorientation caused by grief and also a typographical marker of the journal as a fragmented form in Barthes's wider project of the 
vita nova. ${ }^{604}$ I maintain too that the zebra's skin serves as an organ of perception and inter-

communication not only between himself and his mother but also between human and animal. In choosing such a distinctive animal's coat as the image to represent the erratic experience of grief and love, Barthes reinforces the close proximity between species via the skin as a site of mutual sensation and perception.

In a religious context, Emma Mason champions this inter-awareness and inclusivity. She argues that grace in the Journal "transforms suffering into a meditative or "-"neutral'"- thinking that dissolves the I or ego. No longer an isolated individual, the grace-full subject feels himself or herself to be part of a unified, divine body." ${ }^{615}$ Barthes, she claims, searches for peace in the grace of writing, and while religion is never central stage in the Journal, it is the "grace notes. . . peripheral to it. . . that help Barthes to figure literature as worth believing in, and writing as the dynamic that enables such faith." ${ }^{26}$ The relevance of Mason's theme of "punctive grace" to my argument lies in the idea of inclusivity, in particular a relational ecopoetics founded on equality between human and animal and their historical inter-dependence. This relationality comes to the surface in the motif of the zebra and its stripes, suggestive of non-anthropocentrism,

heterogeneity ${ }_{2}$ and pluralism. The punctum ${ }^{67}$ of the zebra invites us to think of a wider ecopoetic unity (a "co-presence" forged between punctum and studium as Barthes highlights in La

Chambre claire $^{68}$ ) between all living beings, including animals and endangered species. $\stackrel{63}{ }$ Patrick

Chamoiseau claims that an ecopoetic conscience is defined by the understanding that difference and mutation are permanent features of our inherited ecosystem. Variation, he states, is "an aesthetic, it is a principle, but it is also an ethics (that constitutes)" ("une esthétique, c'est un principe, mais il est aussi une éthique [(qui constitue]. $\left.)^{\prime \prime}\right)^{649}[$ "an aesthetic, it is a principle, but it is also an ethics (that constitutes)"]. I would argue therefore that alongside the punctive poetics

Commented [W10]: Rewrite sentence: "The relevance of writing's "punctive grace" to my argument lies in the idea of inclusiveness (Mason's incorporation of the peripheral), and how this is reflected in a relational ecopoetics founded on equality between human and animal and their historical inter-dependence". 
of Barthes's exotic invocation of the zebra's stripes as a metaphor for grief and love, there is an acknowledgement of an ecopoetic conscience that bears witness to a biospheric relation between the animal ecosystem of the zebra and human precarity, and which succeeds in integrating the peripheral (wild, African, irregular) within a European, domestic, and homogeneous vision.

Barthes's poetic ecosystem extends to the "régions" of grief ("atrocious region" ["région atroce"["atrecious region"]; "region of death" ["région de la mort" ["region of death"]; "flat and dreary country — with hardly any water" ["pays plat, morne — sans presque de points d'eau"["flat and dreary country — with hardly any water"]). It is also a region "where I have no longer any fear" ("où je n'ai plus plus peur." $2^{\underline{765} \theta}$ ["where I have no longer any fear" $]^{71}$ This fearless flat region finds its equivalent in the landscape of $\mathrm{Morocco}_{2}$ which Barthes visited intermittently after his mother's death. The first mention of Morocco is in the Suite du Journal that covered the period from June to October 1978. Despite some setbacks with these visits, in particular his reluctance to be around people or groups of friends, however welcoming and friendly, ${ }_{2}^{72}$ Barthes finds peace in this landscape: "a bit of peace and happiness; the depression relents" ("un peu de paix et comme de bonheur; la dépression cèdecede." ${ }^{6673}$ ["a bit of peace and happiness; the depression relents"]. Morocco and consolation are also linked to the natural environment. On the first anniversary of his mother's birthday, he offers her a rose (as he always did) bought from the local market and places it on the table in his hotel room. Re-watching Hitchcock's Under Capricon (1949), starring Ingrid Bergman, it is the carnation in Bergman's hair that captures Barthes's attention. ${ }^{6774}$ In another journal entry from Morocco, he writes: ["I saw the swallows Commented [W12]: Keep as it is. flying in the summer evening. I said to myself - thinking painfully of my mother-what barbarism not to believe in the life of the soul - in the immortality of the soul! What an idiotic truth is materialism!" (声"Je vis les hirondelles voler dans le soir d'été. Je me dis—pensant avec 
déchirement à mam—quelle barbarie de ne pas croire aux âmes—à l'immortalité des âmes!

Quelle imbécile vérité que le matérialisme!"26875-["I saw the swallows flying in the summer

evening. I said to myself - thinking painfully of my mother - what barbarism not to believe in

the life of the

rose ensures a continuity of practice that extends across continents. The skein of swallows

Commented [W13]: Replace continents with "time and space".

captured in $\mathrm{V}$ formation point to the bird's cosmopolitan distribution across the world and the symbolism of communication between life and death. However, the swallow is more than

Barthes's poetic muse as a twin metaphor of flight and the promise of an afterlife where he will reunite with his mother. Barthes succeeds in raising animal and human forms to an ecopoetic space framed by mutual reciprocity, inter-species correspondence, and continuity. Chamoiseau writes: E"It is with this poetics that we must think our fluid identities, our relation to ourselves,

other living creatures and the world. More than 'living-together,'-; it is the idea of 'living-in-

relation' which in my view is conclusive and constitutes the huge challenge we face."

avec cette poétique-là qu'il nous faut penser nos identités fluides, notre rapport à nous-mêmes, aux étants et au monde. Plus que le 'vivre-ensemble', c'est l'idée du 'vivre-en-relation' qui est à mon sens déterminant et qui constitue l'immense défi à relever." $-^{-6976}$ ["It is this

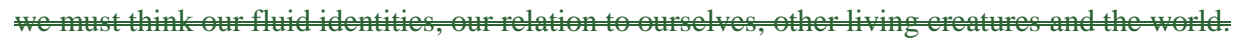

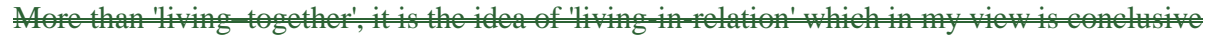
and enstitutes the huge ehallenge faee"].

There are a number of reparative effects to this ecopoetics. One of the key ones is writing $_{2} ;$ not writing as self-disclosure but writing as a "working through" words. Writing has a salvatory effect, and the numerous references to Proust's loss of his mother reinforce this consolation. ${ }^{707}$ Writing too performs the function of memorialization and immortalization. 
Writing enables Barthes to acknowledge that Barthes "the writer" is no longer (

myself recognized again ... create this book about mother" $\exists$ ["il me faut me faire reconnaître de nouveau. . . faire ce livre autour de mam"]). ${ }^{718}$ ["I have to make myself recognized again... marte In short, it is writing that makes grief measurable in its capacity

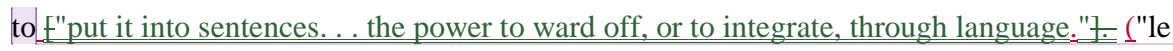

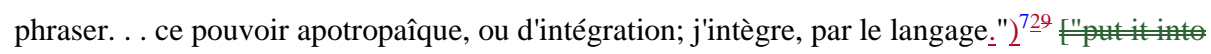
aff, fotnote to this entry Barthes explains what he means by integrate: "'"enter into a group_federate-socialize, communize, form a gregarious group." (“faire entrer dans un ensemble-fédérer-socialiser, communiser, se grégariser." ${ }^{7380}$ "enter into a group federate socialize, commmnize, form a gregarious group"]. On one level, integration seems an implausible response to grief given Barthes's reticence to share his grief with others; his experience of grief's "extériorisation" gives way continually to "intériorisation." However, integration has other meanings. The Journal is a preparation for writing ${ }_{2}^{81}$ and the transition from exteriorization (journal) to interiorization (book) is both personal and integrative..$^{74}$ - Antoine Compagnon argues that once the desire to write returns after the emotion of grief, writing (i.e., narrating the Journal in a form that would become La Chambre claire) becomes the only authentic means of expressing grief. Compagnon expands on this idea claiming that "the aim of grieving literature is not treatment, cure or elegy, but the erection of a monument to death, with a view to another life without betrayal." ("le but de la littérature de deuil n'est pas la cure, la guérison, ou l'élégie, mais le monument élevé au mort, dans l'assomption d'une autre vie sans trahison." $2^{7582}$ ["the aim of grieving literature is not treatment, cure or elegy, but the erection of a monument to death, with a view to another life without betrayal"]. To integrate therefore is to integrate time, which the Journal can only do at 
the superficial level of dates, observations, and prolepsis. The Journal is thus reduced to prefacing the monument of writing that will be constructed over time: "For me, the Monument is not what is durable, eternal (my doctrine is too deeply the idea that everything passes; tombs die too), it is an action that requires acknowledgment." ("Pour moi, le Monument n'est pas le durable, l'éternel (ma doctrine est trop profondément le Tout passe: les tombes meurent aussi), il est un acte, un actif qui fait reconnaître." $)^{7683}$ ["For me, the Monument is not what is durable, eternal (my doctrine is too deeply the idea that everything passes; tombs die too), it is an action that requires acknowledgement"]. The implications are twofold. Writing ("littérature") is a breaking free from the fragmentation and unreliability of the Journal into the vita nova of a form of writing that would come later. Breaking free is also an acknowledgement of language as a living structure with the capacity to capture "le deuil définitif." ${ }^{7784}$ In this, writing is the root of reparation.

I end with an ecopoetic view on the theme of writing as integration. Barthes's corpus is founded on the social and ethical responsibilities of language and writing. ${ }^{7885}$ It is not a surprise therefore to see Barthes highlight this ethics in his footnote on integration. What is peculiar is his use of the verb "se grégariser." "Grégaire" means gregarious (sociable, convivial), but it is more often deployed in animal contexts to refer to flocks or other loosely organized communities of birds, fish ${ }_{2}$ and trees. Gregarious groups stand out because their grouping is not based on a search for fellow creatures but on environmental necessity; gregarious relations thrive on sharing territory or synchronization of activities without the need to form closer familial or reproductive links. As a model for writing as integration, "grégarisme" ensures cohabitation between the ethics of social inclusivity and preservation of individual autonomy. As a metaphor for ecopoetics, "grégarisme" gestures to an aesthetic of inter-species co-presence and inter- 
communication. Ecopoetics is not a mere trope. It is a vision that sustains Barthes's monument of writing as a living organism and a relationality that require that we extend the limits of who we are. Chamoiseau, for whom literature is a similar vital process, endorses this vision: "ELiterature does not tell stories anymore. It reflects the inextricable nature of Relationality. Relationality opens out to the inextricable, that is to say the living. And so contemporary literature can be nothing but relational, conscious, active, trembling and indeterminate. Open to all possibilities!" (1."La littérature ne raconte plus d'histoires. Elle reflète l'inextricable de la Relation. La Relation ouvre à l'inextricable, c'est-à-dire au vivant. Et donc la littérature contemporaine ne peut être que de Relation, consciente, active, tremblante et indéterminée. Ouverte au tout possible!") ${ }^{7986}$ Eiterature does not tellstories anymore. It refleets the inextrieable nature of Relationality.

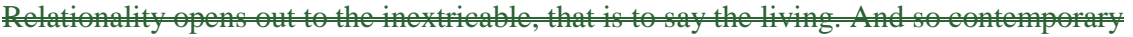
literature can be nothing but relational, conscious, active, trembling and indeterminate. Open to allposibilities!"].

\section{Conclusion}

We have established in this article that reparation is a collaboration between "acting out" and "working through" trauma. It manifests itself in a breaking free into an ecopoetical discourse, itself imbued with ethic, value, and agency. For Sebald, this discourse is evidenced in contact with the vegetal and the earth, primarily in gardens. Contact reinforces the historical continuum between human and non-human, present and past. Ecopoetics also implies a "working through" trauma in a way that lays the seed for an alternative and enduring cosmopolitanism that survives the transience of time, culture, and gender. In Darrieussecq, death is reimagined beyond the mortal body in natural and cosmic spaces. This re-imagination enables the griever to create a new relation with the dead through an "eco-parloir" that consoles by virtue of its historical 
participation in the diverse and harmonious coherence of an ecosystem shared by humans,

animals $s_{2}$ and nature. The grieving Barthes finds reparation in the act of writing as a monument of memorialization and as a space of integration where the trauma of grief is tranquilized in a discourse of inter-species correspondence.

Enda McCaffrey is Professor of French Theory and Culture at Nottingham Trent University. He is the author of a number of books, co-edited collections, and special issues. His research covers the twentieth-century French and European literature, the Medical Humanities, and queer theory.

\section{Notes}

1. Dominick LaCapra, Writing Trauma, Writing History (John Hopkins University Press, 2001) and Mireille Rosello, The Reparative in Narratives: Works of Mourning in Progress (Liverpool University Press, 2010).

2. Pierre Schoentjes, Ce qui a lieu. Essai d'écopoétique (Paris: Wildproject Editions, 2015). See "Écopoétiques," Special Issue of Revue critique de fixxion française contemporaine 11, 2015.

3. Alain Romestaing, Pierre Schoentjes, Anne Simon, "Essor d'une conscience littéraire de l'environnement," Revue critique de fixxion française contemporaine, 3.

4. The phrase "eco-parloir" is used by Stépahnie Posthumus in "L'habiter écologique et l'imaginaire paysan chez Marie-Hélène Lafon et Michel Serres," Revue critique de fixxion française contemporaine, 101-102. Marie Darrieussecq uses a variation of this phrase ("notre parloir" (178)) to convey the reparative effect of nature in addressing the narrator's grief.

5. Cathy Caruth, The Unlimited Experience: Trauma, Narrative and History (Baltimore: The John Hopkins University Press, 1996), 5. Ruth Leys, Trauma: A Genealogy (Chicago: University of Chicago Press, 2000), 2.

6. Marianne Hirsch, "Epi-Memory." Keynote delivered at the Trauma and Gender in 20th Century Literature Conference held at the University of Strathclyde, March 2016.

7. LaCapra, Writing Trauma, 143-144.

8. LaCapra, Writing Trauma, 144-145.

9. Rosello, The Reparative in Narratives, 19.

10. Rosello, The Reparative in Narratives, 16.

11. Ecocriticism has emerged as an umbrella term for a multiplicity of approaches and subjects, including nature writing, deep ecology and eco-theory.

12. Stéphanie Posthumus, "L'habiter écologique," 101-102.

13. Romestaing et al, "Essor d'une conscience," 3. This translation and all subsequent translations are the author's.

14. Patrick Chamoiseau, Hannes De Vriese, "L'écriture de la nature ou le texte vivant," Revue critique de fixxion française contemporaine, 129-130.

15. Marie Cazaban-Maserolles, "L'écologie poétique profonde d'Éric Chevillard," Revue critique de fixxion française contemporaine, 66-67. 
16. Christina Kullberg, "L'écriture arborescente de la Caraïbe," Revue critique de fixxion française contemporaine, 9.

17. Chamoiseau, Hannes De Vriese, "L'écriture de la nature," 130.

18. Arne Naess, Écologie, communauté et style de vie (Paris: Editions MF, 2013).

19. Serenella Iovino, "Ecocriticism and a Non-Anthropcentric Humanism," in L. Volkman, N. Grimm (eds) Local Narratives, Global Responsibilities (Amsterdam: Rodopi, 2011), 44.

20. Cazaban-Maserolles, "L'écologie poétique," 61.

21. Chamoiseau, Hannes De Vriese, "L'écriture de la nature," 131.

22. Chamoiseau, Hannes De Vriese, "L'écriture de la nature," 131.

23. See Anja Johannsen, "The Contrarities that are in our Yearning: Allegorical, Nostalgic and Transcendent Spaces in the Work of W.G. Sebald," Journal of European Studies, 41.3 (2011): 377-393.

24. W.G. Sebald, The Emigrants (London: Vintage, 2002), 21.

25. Sebald, The Emigrants, 22

26. Sebald, The Emigrants, 23.

27. Sebald, The Emigrants, 57.

28. Anja Johannsen, echoing the work of Ruth Klüger on plants and the self-sustaining properties of photosynthesis in Sebald, claims that gardening is beneficial only for the individual and "so does not constitute a way out of the destructive process of regressive regeneration that is inherent in Sebald's conception of nature" (392).

29. Rosello, The Reparative in Narratives, 23.

30. Sebald, The Emigrants, 8.

31. Kullberg, "L'écriture arborescente," 8.

32. Sebald, The Emigrants, 98.

33. Sebald, The Emigrants, 103.

34. Sebald, The Emigrants, 116.

35. For Sebald, life pre-Nazism is synonymous with cosmopolitanism. This is central to Sebald's characterization of his protagonists and the ecopoetics of reparation. Sebald uses their empathy with nature as a way of reclaiming this cosmopolitan vision in the midst of genocide and their own self-destruction. Compare Darrieussecq's use of empathy as a means of connecting with other grievers in Tom est mort (184).

36. Sebald, The Emigrants, 129.

37. Sebald, The Emigrants, 141.

38. Sebald, The Emigrants, 131.

39. In Sebald's novel Austerlitz (2001), the narrator preserves the corpses of dead moths because they remind him of the experience of exile. Moths are "human-like. . with collars and cloaks" (128). It is their "death-like state" with which he identifies (133).

40. Chamoiseau, Hannes De Vriese, "L'écriture de la nature," 131.

41. Missing children are a feature of Darrieussecq's fiction. See Le Mal de mer (1999), White (2003), Le Pays (2005). 
42. Emma Wilson, Cinema's Missing Children (London: Wallflower Press, 2002), 153.

43. Colette Trout, "From Le Bébé to Tom est mort: Writing the Unspeakable Terror of Motherhood," Dalhousie French Studies 98 (2012), 107.

44. Simon Kemp, "The Ghost and the Machine: Minds and Spirits in Darrieussecq," Dalhousie French Studies, 75.

45. Kathryn Robson, "Psychic Plagiarism: The Death of a Child in Marie Darrieussecq's Tom est mort and Camille Laurens's Philippe," French Studies 69.1 (2015): 46-59.

46. Simon Kemp explains the neuronal and synaptic functions in Darrieussecq's fiction as part of a wi der resistance to psychological depth and a tendency to remain at the surface level of cognitive behavior. See Kemp,

"Darieussecq's Mind," French Studies 62. 4(2008): 429-441. For an animal reading of Darrieussecq's fiction, see Anat Pik, "The Indignity of Species in Marie Darrieussecq's Pig Tales," in Creaturely Poetics (New York: Columbia University Press, 2011).

47. Marie Darrieussecq, Tom est mort (Paris: Folio, 2007), 59.

48. Darrieussecq, Tom est mort, 9.

49. Anne Simon, "Marie Darrieussecq ou la plongée dans les 'mondes animaux'," Dalhousie French Studies 98 (2012), 78-79. According to Gilles Deleuze and Félix Guattari, becoming-animal ["devenir-animal"] is the copresence of a particle that both humans and animals share. See Mille Plateaux (Paris: Éditions de Minuit, 1980), 335. For more on Simon's Deleuzian reading of Darrieussecq, see Anne Simon, "Déterritorialisations de Marie Darrieussecq," Dalhouise French Studies 93 (2010): 17-26.

50. Deleuze et Guattari, Mille Plateaux, 53-54.

51. Peter Sloterdijk rejects the existence of dualisms such as body and soul, subject and object. His ideas integrate different components that have been erroneously considered detached from each other. His philosophy proposes the creation of an ontological constitution that incorporates all living things - human, animal, plant and machine.

52. Darrieussecq, Tom est mort, 101.

53. Darrieussecq, Tom est mort, 142.

54. Brenda Garvey, "Embodied Spaces and Out-of-Body Experiences in Le Pays," Dalhousie French Studies 98 (2012): 41.

55. Deleuze and Guattari situate the process of "devenir-animal" as one in which latitude and longitude are the two elements of a cartography. See Mille Plateaux, 261.

56. Darrieussecq, Tom est mort, 110.

57. Suzette Henke, Shattered Subjects: Trauma and Testimony in Women's Life-Writing (Macmillan, 1998$), 76$.

58. Antoine Compagnon, "Écrire le deuil," Acta fabula 14. 2 (2013): 27. See also Wernmei Yong Ade, "Mourning Diary: Love's Work," Textual Practice, 30.2 (2016): 345-362.

59. Punctum conveys the unique detail of the zebra's stripes — white on a black body and irregular in pattern — with no one animal's stripes following the same pattern. See Roland Barthes, Journal de deuil (Paris: Editions du Seuil, 2009), 50.

60. Balzac uses the talismanic and shrinking effects of the shagreen in La Peau de chagrin (1831) to convey the 
pull of desire over knowledge.

61. Claudia Benthien, Skin: On the Cultural Border between Self and the World (New York: Columbia University Press, 2004), 236-237.

62. Seema Ladsaria and Rajani Singh, "The 'Semiotic Animal' in Roland Barthes: A Reflection on Calculating the Self as 'Difference in Man'," Journal on Interdisciplinary Studies in the Humanities 3, 2 (2016): 24-34.

63. Barthes, Journal de deuil, 50.

64. Darrieussecq compares grieving parents who attend therapy groups to zebras shuffling together shin by shin (175).

65. Emma Mason, "Punctive Grace: Reading Religion in Barthes's Mourning Diary," Textual Practice 30.2 (2016): 327.

66. Mason, "Punctive Grace," 330.

67. In Barthes's study of photography, the punctum is an accidental detail that pierces the consciousness of the viewer. The punctum contrasts with the studium and its general impact. In the Journal, instances of the punctum are set against cultural and hegemonic understandings of what constitutes grief.

68. Barthes emphasizes the idea of "co-présence" between studium and punctum in La Chambre claire (Éditions Gallimard Seuil, 1980), 71-72.

69. Chamoiseau, Hannes De Vriese, "L'écriture de la nature," 128.

70. Barthes, Journal de deuil, 63.

71. Compagnon draws a comparison between Barthes's flat landscape of grief and Baudelaire's melancholia in "Écrire le deuil," 25.

72. Barthes uses the word "Acédie" to describe one of the many symptoms of grief. Acedia is listlessness. Barthes describes it as a "sécheresse de coeur" ["a drought of the heart"]—an inability to care for anyone (lover or friend), including a lack of desire to make new friends.

73. Barthes, Journal de deuil, 176.

74. These references (cinematic primarily) are different to what Barthes calls the punctum in La Chambre claire, and which he attributes to photography. Antoine Compagnon however suggests that the cinematic harbors an emotive quality that lends itself to the punctum.

75. Barthes, Journal de deuil, 171.

76. Chamoiseau, Hannes De Vriese, "L'écriture de la nature," 130

77. Adam Watt, "Reading Proust in Barthes's Journal de deuil," Nottingham French Studies 53. 1 (2014): $102-112$.

78. Barthes, Journal de deuil, 144.

79. Barthes, Journal de deuil, 144.

80. Barthes, Journal de deuil, 187.

81. There are multiple references in the Journal to the idea that what Barthes is writing now is a preparation for his book on photography.

82. Compagnon, "Écrire le deuil," 21.

83. Barthes, Journal de deuil, 187. 
84. Compagnon, "Écrire le deuil," 21

85. Roland Barthes, Le Degré zéro de l'écriture (Paris: Seuil, 1953) and Le Plaisir du texte (Paris: Seuil, 1972).

86. Chamoiseau, Hannes De Vriese, "L'écriture de la nature," 132. 